\title{
The Effect of a Psycho-Training Program Designed to Increase Optimism on Secondary School Students
}

\author{
Assoc. Prof. Dr. Pervin Nedim Bal ${ }^{*}$ \\ Beykent University, Faculty of Art and Sciences, Department of Psychology \\ Ayşe Yıldız \\ Istanbul University, Faculty of Education, Psychological Counseling and Guidance
}

\begin{abstract}
The purpose of this study was to investigate the efficiency of a psycho-training program designed to increase optimism levels of the secondary school students. Pre-test post-test control group design was used in the study. "Life Orientation Scale", which was developed by Scheier and Carver (1987) and adapted by Aydın and Tezer (1991), was applied to the $8^{\text {th }}$ graders of Istanbul Avc1lar Cihangir State School in 2015-2016 academic year. 24 voluntary students with low optimism levels were selected, then, 12 of them were randomly assigned as experimental group, and the other 12 were assigned as control group. Psycho-training program was applied to only experimental group for one and half hour for eight weeks. Control group was not exposed to any manipulation. The independent variable in this study was psycho-training program and the dependent variable was the optimism level of the students. For the analysis of the data Mann- Whitney U test was used for intergroup differences and Wilcoxon Signed Rang Test was used for intra-group differences. The results of the study indicate that psycho-training program designed to increase optimism levels has been effective in increasing optimism levels of the students in experimental group.
\end{abstract}

Keywords: Optimism, Secondary school students, Psycho-training program

China insurance industry, Foreign fund, Challenge

DOI: $10.7176 /$ RHSS/9-2-07

\section{Introduction}

In this study, it is aimed to increase the level of optimism of adolescents with the Psycho-training program prepared on the base of Cognitive Behavioral Approach. Nowadays, adolescents have become increasingly unhappy, have high levels of depression and become pessimistic (TUIK, 2009-2012). In this turbulent period where physical and psychological changes occur, $8^{\text {th }}$ grade students are preparing for the "Teog exam" (high school entrance exam), which they consider to have an important place in their lives. In these difficult times, where the expectation of academic success has increased considerably, and at the same time they have to cope with various physical and emotional changes, in addition to their cognitive development, they need support in the emotional sense. Together with the effect of positive psychology, psychology, which studies abnormally and negatively, has included positive and normal studying subjects. For this purpose, researchers focus on topics such as happiness, subjective well-being, satisfaction with life, and speed up studies on many different positive personality traits. Optimism also attracts attention as a personality trait that studies within the scope of positive psychology has gained speed (Uğurlu, 2011, s.81). Educational institutions have an important function to increase the academic success of individuals. In positive psychology, there are subject areas that affect the academic success of individuals. One of these subject areas is optimism. Organizing educational guidance activities on optimism will contribute to the maturation and development of students in psychological and academic terms. For this reason, there should be optimism about the academic achievement at the center of the educational guidance studies. Specialists from the educational background are encouraged to become academically optimistic by bringing the positive experiences of the past into the future, by highlighting past individuals' successful academic experiences (Eryılmaz, 2013, s. 8-12). Researchers interested in positive psychology have considered optimism as a concept that should be taught to individuals. When optimism is learned, problem solving skills of people will increase and they will be able to cope with stressful living conditions more easily. Even the slightest change in people's negative perspectives through optimism will have a great importance in their lives. (Eryılmaz,2013, s.7). Goleman (2000) defined optimism as a strong feeling and expectation that everything will go well in life despite difficulties and obstructions (cited in Parmaksiz ve Avşaroğlu, 2012, s.546). Individuals with optimistic characteristics have a positive expectation of better things in the future by focusing on the more appropriate and positive side of the events they face. This is expressed in terms of the attributional approach, in which the optimists focus on their positive past experiences and have the ability to enter the positive expectations of the future (Seligman, 1990, s.4-5). While Seligman sees pessimism as a condition that raises the effects of depression, causes a person to feel ill and is associated with negative physical health symptoms, he evaluates optimism, positive emotions, high morale, perseverance and effective problem solving, academic, military, professional success, popular, healthy life and as an important way to get 
rid of trauma (Seligman, 1990; s.54-56). Optimism has the power to withstand difficulties in order to continue life effectively in spite of the difficulties of life. The concern that things will not work is likely to stress people. If this concern is kept under control, the path to the solution is opened. Therefore, generally the situation itself is not stressful, the point of view is stressful (cited in Parmaksız ve Avşaroğlu, 2012, s.546). An optimistic attitude is an attitude that protects individuals from being indifferent, hopelessness or depressed in face of difficulties. Optimists like the pessimists go through the same life experiences; the difference is that the optimists are able to overcome these events more successfully and learn from their mistakes and they recover themselves more quickly after the defeat. Optimism can be seen as both a personality trait and a way of thinking, which includes tendencies to expect positive results. It can be thought that the personality traits of people affect the positive or negative expectations they have constructed in relation to the results of their experiences, the way they handle their experiences, the way they deal with life events and their well-being (Türküm, 1999, s.77). Optimism; it is a concept that accommodates expectations, planning, logic and action. The individual should have realistic expectations about the possibility of encountering positive events. With the same realistic expectations, he / she should make a reasonable plan to solve the event and must have the energy and power to act and fight the negative situation. In this case, optimism can be seen both as an emotion and as a learnable, developable feature. (Gençoğlu, 2006, s.10). Türküm (1999, p.77-78) explains the concept of optimism with the concepts of comparative optimism and unrealistic optimism. In comparative optimism, the individual thinks that he / she will have a higher probability than others to encounter with positive events. In Unrealistic optimism; the individual has a tendency to perceive that the likelihood of occurrence of positive events may be higher than the actual, on the other hand, the likelihood of occurrence of negative events will be lower than it may actually be. In this study, the concept of comparative optimism will be emphasized.

Studies show a positive relationship between optimism and subjective well-being (Eryllmaz and Atak, 2011 p.171; Öztürk, 2013, p.iii; Durdun, 2012, p.96). Uğurlu (2011, p.81) found that optimism positively correlated with general health and mental health, but pessimism was negatively associated with both general health and mental health. Kümbül Güle and Emeç (2006, s.146) concluded that there was a positive relationship between optimism and life satisfaction in the study of the effects of optimism on life satisfaction levels of university students. In another study, it was determined that there was a high positive correlation between optimism and self-esteem, and that there was a negative correlation between depression and optimism (Parmaksiz ve Avşaroğlu, 2012, s. 545). In addition, positive relationship was observed between self-recovery power (Terzi, 2008; p.297), psychological stability (Eryılmaz, 2012, p.89) and optimism. Gençoğlu (2006, p.98) found that students with low level of optimism have low self-actualization, low emotional stability whereas students with high level of optimism have high self-fulfillment and emotional stability. The neurotic and psychotic tendency levels of the students with high level of optimism is low and the neurotic and psychotic tendency levels of the students with low level of optimism were found to be higher. It is also stated that there is a positive relationship between the level of optimism and family relations and social relations of the students.

There are many studies showing that optimism is related to physical health. In a meta-analysis of 84 studies on optimism and physical health, Rasmussen et al. (2009, p.239) suggested that optimism is a significant predictor of physical health and that optimism plays a positive role in physical health. In a study on cancer patients, it was reported that women with high level of optimism have better social and cognitive functioning than those with low optimism (Colby and Shifren, 2013; p.10). In another study, optimism was associated with low anxiety, low depressive symptoms, low level of hopelessness and high quality of life (Applebaum et al., 2014 ; p.299). In addition, other studies reported higher quality of life, health (Wang et al., 2014), self-regulation (Carver, 2014; p.24), well-being (Olson et al. 2014, s.376), positive physical function (Wurm et al., 2014; p.832), high social support (Brissette et al., 2002; p.102), positive with physical and mental health (Patton et al., 2011; p.127); anger, hostility verbal aggression, borderline tendency, depressive symptoms (Wurm et al., 2014; p.832), stress and depression (Brissette et al. 2002; p.102), heart disorders (Kim, Smith and Kubzansky, 2014; s .394). Kim, Chopic and Smith (2014; p.447) stated that there was a positive relationship between the individual's optimism and the optimism of his spouse and the physical health and physical activity he perceived. They stated that people with better optimism suffer from less chronic diseases and people with an optimistic partner have better physical health and less chronic discomfort.

Peterson suggests that cognitive therapy can change the pessimistic manner of expression with optimistic explanation and stated that children's pessimistic forms of expression can be changed to optimistic explanations with cognitive behavioral interventions such as problem solving skills practices (Peterson and Steen, 2005). Carver and Scheier (2005) report that hereditary and environmental factors are effective on pessimism and optimism, however, they largely indicate that childhood experiences lead to the formation of these personality traits. They stated that in the framework of the cognitive behavioral approach, the pessimistic viewpoint can be transformed into an optimistic outlook, with the change of unrealistic beliefs such as I will never succeed (cited in Avc1, 2009, p.4).

In summary, studies have shown that optimism has an important place in the psychological and physical 
health of individuals. On the other hand, researchers have shown that optimism can be learned and increased. From this point of view, optimism is a feature that is of great importance on the health of individuals. Learning and application of optimism have many effects on all life areas of an individual. Optimism is important as a personality trait that can affect many factors within the school life, such as academic achievement, and also affect adulthood. Since optimism is a learned concept and has a positive relationship with many concepts such as health, academic achievement and social cohesion, it is thought that this study will be effective in both academic and psychological and social lives of the students who will take the TEOG exam. Also, the number of research in Turkey for learning optimism is quite limited. For this reason, it is thought that it will contribute to other researchers, Psychologist and Psychological Counseling and Guidance.

\section{Method}

\subsection{Design of Research}

Pre-test post-test control group design was used in the study. "Life Orientation Scale", which was developed by Scheier and Carver (1987) and adapted by Aydın and Tezer (1991), was applied to the $8^{\text {th }}$ graders of Istanbul Avcrlar Cihangir State School in 2015-2016 academic year. From 82 students 24 voluntary students with low optimism levels were selected, then, 12 of them were randomly assigned as experimental group, and the other 12 were assigned as control group. The training program which was prepared by the researchers on the base of cognitive behavioral approach was only given to the experimental group for an hour and half per week for eight weeks to help the students (the experimental group) to enhance their optimism level. The control group wasn't exposed to any treatment. At the end of training, "Life Orientation Scale" (post-test) was again applied to the both experimental and control groups. All students were volunteers to join the study. The independent variable of the study was the Psycho-training Program and the dependent variable was the level of optimism.

\subsection{Study group}

$828^{\text {th }}$ grade students attending the Cihangir state secondary school in Avcrlar, Istanbul were given the Life Orientation Test and 24 students with low level of optimism to participate in the psycho-training program to increase the level of optimism were identified. The students were randomly assigned to the experimental and control groups with 12 girls and 12 boys, 6 boys and 6 girls for experimental group and 6 boys and 6 girls to the control group. All participants were volunteered.

\subsection{Hypotheses}

The purpose of this study was to investigate the efficiency of a psycho-training program designed to increase optimism levels of the secondary school students. The general hypothesis of this study is that the psycho-training program designed to increase optimism levels will be effective on increasing the optimism levels of the secondary school $8^{\text {th }}$ grade students. Therefore, it was hypothesized that there is no any significant difference between pre-test scores of experimental group and control group; there is no any significant difference between pre-test scores and post-test scores of control group; there is a significant difference between pre-test scores and post-test scores of experimental group; there is a significant difference between post-test scores of the experimental group and the control group.

\subsection{Data Collection Tools}

2.4.1. Life Orientation Test: The Life Orientation Test (LOT) developed by Scheier and Carver (1987) was adapted into Turkish by Aydın and Tezer (1991). LOT is a 5-grade Likert-type scale consisting of 12 items. Some items in the scale are scored reversely to prevent the tendency to respond positively. There are also four items on the scale that are not scored in any direction (neutral items). A single score is obtained by summing the numerical values of the options that the subjects have marked. The lowest score is 0 and the highest score is 32 . High score indicates positive viewpoint, in other words optimism. To determine the reliability of the LOT the Pearson product-moment correlation coefficient was .77 and Cronbach's alpha coefficient was .72. To determine the validity of the LOT, the correlation between the Beck Depression Inventory and LOT was calculated and revealed a significant and negative correlation (-.56).

2.4.2. Psycho-training Program for Increasing Optimism: The main goal of the psycho-training program was to increase optimism levels of the $8^{\text {th }}$ grade secondary school students, and the sub-goals of the program were to define the concept of the optimism and to conceptualize optimism and pessimism; to differentiate optimism and Pollyannaism; to be able to evaluate their own optimism level; to be able to give examples of optimism and pessimism thoughts from their own lives; to train the students verbalize their thoughts and feelings about their personal optimism behavior; to train the students differentiate feelings and thoughts and identify the relationship between thoughts and feelings; to train the students to be aware of negative thoughts and to be able to produce positive thoughts instead of negative thoughts; to be able to notice their irrational believes and be able to interrogate the irrational believes and convert irrational believes to the rational believes; to be able to 
differentiate the effect of optimism and pessimism on their bodily responses; to train the students to understand personalization and generalization and the possible mistakes done on them. To increase optimism, the activities were prepared for the following purposes.

1) To be able to comprehend the concepts of optimism pessimism,

2) To distinguish optimism and pollyannaism,

3) To evaluate the level of optimism of group members,

4) Give examples of optimistic pessimistic thoughts from the lives of the group members,

5) To distinguish between emotions and thoughts and to be able to recognize the relationship between

6) Recognition of negative thoughts,

7) To be able to produce positive thoughts instead of negative thoughts,

8) To be able to recognize irrational beliefs,

9) To be able to question irrational beliefs,

10) To transform irrational beliefs into rational beliefs,

11) To be able to recognize the difference between tension and relaxation,

12) To be able to recognize the effect of optimism and pessimism on the bodily reactions,

13) Personalization, generalization, retention of concepts

0statistical technique for data analysis, the size of the groups used in the study was taken into consideration. When the size of the sample falls below 15, it is difficult to assume that the scores are normally distributed and therefore non-parametric techniques are preferred (Büyüköztürk, Çokluk and Köklü, 2010). Thus, the data obtained in the study were analyzed by nonparametric statistical methods. For this purpose, Mann Whitney U test was used to compare the two groups (intergroup), the experimental group and control group. The Wilcoxonmarked sequence test was used to compare intra-group. The data were calculated by using SPSS software. The significance level of $\alpha=.05$ was taken into account in interpretation of the results

\section{Results}

Results of the pre-test and post-test mean scores of the experimental and control groups are given in Table 1.

Table 1. Pre-test and post-test mean scores of experimental and control groups

\begin{tabular}{|c|c|c|c|c|}
\hline & & $\mathrm{N}$ & $\mathrm{X}$ & $\mathrm{Sd}$. \\
\hline \multirow{2}{*}{$\begin{array}{c}\text { Experimental } \\
\text { Group }\end{array}$} & Pre-test & 12 & 11,33 & 2,462 \\
\cline { 2 - 5 } & Post-test & 12 & 14,42 & 2,678 \\
\hline \multirow{2}{*}{ Control Group } & Pre-test & 12 & 11,25 & 2,301 \\
\cline { 2 - 5 } & Post-test & 12 & 11,33 & 2,309 \\
\hline
\end{tabular}

As shown in Table 1., the average of the optimism scores of the students participating in the study is examined. The pre-test score of the experimental group was 11.33 and the pre-test score of the control group was 11.25. The pre-test mean score of the experimental group was 11.33 and the post-test mean was 14.42 . While the mean pre-test score of the control group was 11.25, the posttest mean score was 11.33 .

\section{Results of the pre-test mean scores of the individuals in the experimental and control groups}

Hypothesis 1: There is no significant difference between the pre-test scores of the experimental group students attending the optimism psycho training program and the pre-test scores of the control group students who did not participate in the program.

Table 2. Results of the Mann-Whitney U test to determine the significance of the difference between the pre-test total scores of the experimental and control groups

\begin{tabular}{|c|c|c|c|c|c|c|}
\hline & & $\mathrm{N}$ & Seq. Av. & Seq. T.. & U & P \\
\hline \multirow{2}{*}{ Pre-test } & Exp. Group & 12 & 12.27 & 135.00 & \multirow{2}{*}{69.000} & \multirow{2}{*}{.883} \\
\cline { 2 - 6 } & Cont. Group & 12 & 12.69 & 165.00 & & \\
\hline
\end{tabular}

When the averages of optimism scores of the students were examined; the pre-test score of the experimental group $(11,33 \pm 2,462)$ and the pre-test score of the control group $(11,25 \pm 2,301)$ were observed. The MannWhitney $U$ test was used to determine whether there was a significant difference between the pre-test scores of the experimental and control groups. It was found that there was no significant difference between experimental and control groups $(u=69,000, p>.05)$. This result shows that the students in the experimental and control groups started to apply in similar conditions in terms of optimism.

Results of the pre-test and post-test mean scores of the individuals in the experimental group

Hypothesis 2: There is a significant difference between the pre-test and post-test scores of the experimental group in favor of the post-test. 
Table 3. Results of Wilcoxon Signed Ranks test for the comparison of pre-test and post-test scores of the experimental group

\begin{tabular}{|l|l|c|c|c|c|c|}
\hline & & $\mathrm{N}$ & Seq. Av. & Seq. T. & $\mathrm{Z}$ & $\mathrm{P}$ \\
\hline Post-test & Negative Seq. & 0 & 0.00 & 0.00 & & \\
Pre-test & Positive Seq. & 12 & 6.50 & 78.00 & -3.114 & .002 \\
& Equal & 1 & & & & \\
\hline
\end{tabular}

When the average of the optimism scores of the students in the experimental group were examined; pre-test scores $(11,33 \pm 2,462)$ and post-test scores $(14,42 \pm 2,678)$. The Wilcoxon Signed Ranks Test was used to determine whether there was a significant difference between the pre-test and post-test scores of the experimental group. The difference between the pre-test and post-test scores of the participants in the experimental group was statistically significant $(z=-3,114, p<0.05)$. It is understood that this difference observed in favor of the positive sequences in favor of the post- test, considering the sequence average and sequence differences of the difference points. Accordingly, the experimental procedure was effective in improving the optimism of the participants.

Findings related to the pre-test and post-test mean scores of individuals in the control group

Hypothesis 3: There is no significant difference between the pre-test and post-test scores of the control group students who do not participate in the optimism psycho-training program.

Table 4. Wilcoxon Signed Ranks test results for the comparison of pre-test and post-test scores of the control group

\begin{tabular}{|c|c|c|c|c|c|c|}
\hline & & $\mathrm{N}$ & Seq. Av. & Seq. T. & $\mathrm{Z}$ & $\mathrm{P}$ \\
\hline \multirow{2}{*}{$\begin{array}{c}\text { Post-test } \\
\text { Pre-test }\end{array}$} & Negative Seq. & 2 & 3.00 & 6.00 & & \\
\cline { 3 - 5 } & Positive Seq. & 3 & 3.00 & 9.00 & \multirow{2}{*}{-.447} & \multirow{2}{*}{.655} \\
\cline { 3 - 5 } & Equal & 7 & & & & \\
\hline
\end{tabular}

When the average of the optimism scores of the students in the control group were analyzed; pre-test scores $(11,25 \pm 2,68)$ and post-test scores $(11,33 \pm 2,30)$. The Wilcoxon Signed Ranks Test was used to determine whether there was a significant difference between the pre-test and post-test scores of the control group. It was found that the difference between the pre-test and post-test scores of the participants in the control group was not significant $(\mathrm{z}=-.447, \mathrm{p}>0.05$ ). So there was no significant change in the optimism scores of the control group.

\section{Findings related to post-test mean scores of individuals in experimental and control groups}

Hypothesis 4: There is a significant difference between the post-test scores of the experimental group students who participated in the optimism psycho training program and the post-test scores of the control group students who did not participate in the program.

Table 5. Results of the Mann-Whitney U test to determine the significance of the difference between the poettest total scores of the experimental and control groups

\begin{tabular}{|l|l|l|l|l|l|l|}
\hline & & $\mathrm{N}$ & Seq. Av. & Seq. T. & $\mathrm{U}$ & $\mathrm{P}$ \\
\hline \multirow{2}{*}{ Post-test } & Exp. Group & 12 & 16.23 & 178.50 & \multirow{2}{*}{30.50} & \multirow{2}{*}{.017} \\
\cline { 2 - 5 } & Cont. Group & 12 & 9.35 & 121.50 & & \\
\hline
\end{tabular}

When the average of optimism scores of the students were examined; the post-test score of the experimental group $(14,42 \pm 2,68)$ and the post-test score of the control group $(11,33 \pm 2,30)$ were observed. There was a significant difference between the post-test scores of the experimental and control groups as a result of the Mann-Whitney $U$ test $(U=30.50, p<0.05)$. Considering the averages, it is understood that the optimism scores of the students who participated in the psycho-training program of optimism were higher than the students who did not participate in the program. This finding shows that the optimism intervention program is effective in increasing the level of optimism of the students in the experimental group.

\section{Conclusion, Discussion and Suggestions}

Optimism has been one of the important issues addressed in the field of positive psychology in recent years. In order to be satisfied with life, individuals need to have a realistic optimistic view of the situations they face. In this study, it was aimed to increase the level of optimism of adolescents through the psycho-training program. The findings also show that the program is effective in increasing the level of optimism of adolescents. Experimental studies on optimism in Turkey and abroad also support the result. When we look at the studies conducted in Turkey, Avc1 (2009; p.76) stated that there is an increase in the optimism scores of the students in the study that tested the effectiveness of the learned optimism training program. In another study, it was stated that the psychological support program applied to mothers of children with intellectual disabilities increased the level of optimism of participants (Vural, 2010; 94). Gençoğlu (2012, s.iii) also reported that emotional awareness training based on emotion-focused therapy was effective in increasing the optimism of young people. Furthermore, there are studies showing that empowerment of emotions (Balc1 Çelik, 2008; p.790), communication skills training (Kutlu, Balc1 and Y1lmaz, 2004; p.7) and positive thinking training (Karagöz, 
2011; p. 81) increase optimism. Findings that these studies conducted in Turkey increase optimism are consistent with findings of this research.

Gillham, Reivich, Jaycox, and Seligman (1995) found that children in the experimental group had decreased depressive symptoms compared to children in the control group. It was determined that the children in the experimental group had more optimistic explanation rates compared to the control group (cited in Avc1, 2009, p.28). Seligman, Schulman and DeRubeis (1999, p.1) concluded that the level of optimism of the experimental group after cognitive behavioral training applied to pessimistic students. In the experimental study conducted on patients receiving cancer treatment, it was reported that the level of optimism of the patients in the experimental group increased (Lee et al., 2006; p.3133). In another experimental study, it has been reported that positive results have been obtained in the improvement of well-being at least in the short term as a result of the optimism training program (Sergeant, Mongrain, 2014; p.263). As a result of the optimism program based on a cognitive behavioral approach, it was stated that the patients' optimism level was increased, they had decline in depression and their social interactions were improved (Frothingham, 2005; p.1). In the light of this information, it can be said that the results of this study are consistent with the studies conducted at home and abroad.

In conclusion, in this study, a group psycho-training program which aims to raise the level of optimism of students based on cognitive behavioral approach was developed for $8^{\text {th }}$ grade students with low level of optimism. For this purpose, pre-test and post-test scores of the experimental and control groups were compared and the effectiveness of the psycho-training program for increasing optimism was investigated. As a result of the statistical analyzes, it was found that the psycho- training program applied was effective in increasing the level of optimism significantly. In Turkey, efforts to increase optimism are limited. Therefore, it is recommended that studies should be carried out with samples with different characteristics and different educational levels. In this study, no follow up studies were conducted. In the new studies to be done, follow up can be done and the permanence of the program can be tested. In this study, the placebo group was not used. In future studies, the effectiveness of the program can be tested using the placebo group.

\section{References}

Applebaum, A.J., Stein, E.M., Bessen, J.L., Pessin, H., Rosenfeld' B. \& Breitbart, W. (2014). Optimism, social support, and mental health outcomes in patients with advanced cancer. Psycho-Oncology, 23(3): 299-306.

Avcı, D. (2009). Öğrenilmiş İyimserlik Ĕ̈itim Programının 9. Ve 10. Sınıf Öğrencilerinin İyimserlik Düzeylerine Etkisi. Yayınlanmamış Yüksek Lisans Tezi, Gazi Üniversitesi, Ankara.

Balcı Çelik, S. (2008). Duyguları Güçlendirme Eğitimi Programı'nın Hemşirelerin İyimserlik Düzeylerine Etkisi. Kuram ve Uygulamada Ĕgitim Bilimleri, 8 (3):781-804.

Brissette, I., Scheier, M.F. \& Carver, S.C. (2002). The Role of Optimism in Social Network Development, Coping, and Psychological Adjustment During a Life Transition. Journal of Personality and Social Psychology, 82( 1): 102-111.

Büyüköztürk, Ş., Çokluk, Ö., Köklü, N. (2010). Sosyal Bilimler İstatistik. Pegem Akademi Yayınları, Ankara.

Carver, S.C. (2014). Self-Control and Optimism are Distinct and Complementary Strengths. Personality and Individual Differences, 66:24-26.

Colby, D.A. \& Shifren, K. (2013). Optimism, mental health, and quality of life: A study among breast cancer patients. Psychology, Health \& Medicine, 18(1): 10-20.

Dursun, P. (2012). The Role of Meaning In Life, Optimism, Hope, and Coping Styles in Subjective Well-Being. Yayınlanmamış Doktora Tezi, Ortadoğu Teknik Üniversitesi: Ankara.

Eryılmaz, A. \& Atak, H. (2011). Ergen Öznel İyi Oluşunun Öz Sayg1 Ve İyimserlik Eğilimi İle İlişkisinin İncelenmesi. Elektronik Sosyal Bilimler Dergisi, 10(37):170-181.

Eryılmaz, A. (2013). Pozitif psikolojinin psikolojik danışmanlık ve rehberlik alanında gelişimsel ve önleyici hizmetler bağlamında kullanılması, The Journal of Happiness \& Well-Being. 1(1):1-17.

Eryılmaz, S. (2012). Üniversite Öğrencilerinde Psikolojik Sağlamlı̆̆ı Yordamada, Yaşam Doyumu, Benlik Saygısı, Iyimserlik ve Kontrol Odağının Incelenmesi. Yayınlanmamış Yüksek Lisans Tezi, Muğla Üniversitesi, Muğla.

Frothingham, S.S.(2005). The Effects Of An Optimism-Based Cognitive Behavioral Intervention on Mood and Functioning in Cardiac Patients, University of Southern Mississippi.

Gençoğlu, C. (2012). Duygu Odaklı Terapiye Dayalı Duygusal Farkındalık Ĕ̆itiminin Genç Yetişkinlerin Iyimserlik Düzeylerine Etkisi. Yayınlanmamış Yüksek Lisans Tezi, Ondokuz Mayıs Üniversitesi, Samsun.

Gençoğlu, C. (2006). Üniversite Öğrencilerinin İyimserlik Düzeyleri ile Kişilik Özellikleri Arasındaki İlişkinin Incelenmesi. Yayınlanmamış Yüksek Lisans Tezi, On Dokuz Mayıs Üniversitesi, Samsun.

Karagöz, Y. (2011). Olumlu Düşünme Eğitim Programının Ergenlerin Geleceğe Yönelik İyimserlik, Depresyon Ve Bilişsel Çarpıtma Düzeylerine Etkisinin Incelenmesi. Yayınlanmamış Yüksek Lisans Tezi, Dokuz Eylül Üniversites, İzmir.

Kim, E.S., Smith, J. \& Kubzansky, L.d. (2014). Prospective Study of the Association Between Dispositional 
Optimism and Incident Heart Failure. Circulation Heart Failure, 7:394-400.

Kim, E.S., Chopic, W.J. \& Smith, J. (2014). Are People Healthier İf Their Partners Are More Optimistic? The Dyadic Effect Of Optimism on Health Among Older Adults. Journal of Psyhosomatic Research, 76(6): 447-453.

Kutlu, M., Balcı, S. \& Yılmaz, M. (2004). "İletişim Beceri Eğitiminin Öğrencilerin Kendini Ayarlama Ve İyimserlik Düzeylerine Etkisi”. XIII. Ulusal Eğitim Bilimleri Kurultayı.

Kümbül Güle, B. \& Emeç, H. (2006). Yaşam Memnuniyeti Ve Akademik Başarıda İyimserlik Etkisi. D.E.Ü.İ.I.B.F. Dergisi, 21(2):129-149.

Lee, V., Cohen, S.R., Edgar, L., Laizner, A.M. \& Gagnon, A.J. (2006). Meaning-Making İntervention During Breast Or Colorectal Cancer Treatment İmproves Self-Esteem, Optimism, And Self-Efficacy. Socia Science \&Medicine, 62(12):3133-3145.

Olson, E.A., Fanning, J.T., Awick, E.A., Chung, H. D. \& Mcauley, E. (2014). Differential Trajectories of WellBeing in Older Adult Women: The Role of Optimism. Applied Psychology: Health and Well-Being, 6(3): 362-380.

Öztürk, A. (2013). Uludağ Üniversitesi Eğitim Fakültesi Öğrencilerinin Öznel İyi Oluş Düzeyleri İle Tinsellik, Iyimserlik, Kaygı Ve Olumsuz Duygu Düzeyleri Arasındaki Illişki. Yayınlanmamış Yüksek Lisans Tezi, Uludağ Üniversitesi, Bursa.

Parmaksız, İ. \& Avşaroğlu, S. (2012). Examining the Teacher Candidates' Levels of Optimism and Styles of Coping with Stress According to Their Self-Esteem Levels. Ilkögretim Online, 11(2): 543-555.

Patton, G.C., Tollit,M.M., Romaniuk, H., Spence, S.H., Sheffield, J. \& Sawyer, M.G. (2011). A Prospective Study of the Effects of Optimism on Adolescent Health Risks. Pediatrics Official Journal of American Academy of Pediatrics, 127-308.

Rasmussen, H. N., Schier, M.F. \& Greenhouse J.B. (2009). Optimism and Physical Health: A Meta-analytic Review. Annals of Behavioral Medicine, 37(3):239-256.

Seligman, M. E. P. (1990), Learned Optimism: How to Change Your Mind and Your Life, New York: Pocket Books.

Seligman, M., Schulman, P. \& DeRubeis, R. J. (1999). The prevention of depression and anxiety. Prevention \& Treatment, 2(8): 1-24

Sergeant, S. \& Mongrain, M. (2014). An Online Optimism İntervention Reduces Depression in Pessimistic İndividuals. Journal of Consulting and Clinical Psychology, 82(2):263-274

Terzi, Ş. (2008). Üniversite Öğrencilerinde Kendini Toparlama Gücünün İçsel Koruyucu Faktörlerle İlişkisi. Hacettepe Üniversitesi Ĕ̆itim Fakültesi Dergisi, 35: 297-306

Türkiye İstatistik Kurumu (TUİK). (2009-2012). Türkiye Sağlı Araştırması verileri. http://www.tuik.gov.tr/Kitap.do?metod=KitapDetay\&KT_ID=1\&KITAP_ID=223 adresinden alınmıştır (alınış tarihi: Ocak 2015).

Türküm, S. (1999). Stresle Başa Çıkma ve İyimserlik. Eskişehir: Anadolu Üniversitesi Yay.

Uğurlu, O. (2011). Genel ve Zihinsel Sağlığın Yordayıcıları Olarak İyimserlik ve Karamsarlık. Çankaya University Journal of Humanities and Social Sciences, 8(1):81-90.

Ulusoy, Y. \& Duy, B. (2013). Öğrenilmiş İyimserlik Psiko-eğitim Uygulamasının Öğrenilmiş Çaresizlik ve Akılcı Olmayan İnançlar Üzerindeki Etkisi. Kuram ve Uygulamada Ĕ̌itim Bilimleri, 13(3):1431-1446.

Vural, M. (2010). Psikolojik Destek Programının, Hafif Düzeyde Zihinsel Yetersizliği Olan Çocukların Annelerinin Umutsuzluk, Iyimserlik ve Pozitif-Negatif Duygu Düzeylerine Etkisi. Yayınlanmamış Yüksek Lisans Tezi, Uludağ Üniversitesi, Bursa.

Wang, Q.F., Hay, M., Clarke, D. \& Menahem, S. (2014). Associations Between Knowledge of Disease, Depression and Anxiety, Social Support, Sense of Coherence and Optimism with Health-Related Quality of Life in an Ambulatory Sample of Adolescents with Heart Disease. Cardiology in The Young, 24(1): 126133

Wurm, S. \& Benyamini, Y. (2014). Optimism Buffers the Detrimental Effect of Negative Self-Perceptions of Ageing on Physical and Mental Health. Psychology \& Health, 29(7): 832-848.

Yalım, D. (2007). First Year College Adjustment: The Role of Coping, Ego-Resiliency, Optimism and Gender. Yayınlanmamış Yüksek Lisans Tezi, Ortadoğu Teknik Üniversitesi, Ankara.

\section{Extended Summary}

\section{Introduction}

The purpose of this study was to investigate the efficiency of a psycho-training program designed to increase optimism levels of the secondary school students. The general hypothesis of this study is that the psych-training program designed to increase optimism levels will be effective on increasing the optimism levels of the secondary school $8^{\text {th }}$ grade students. Therefore, it was hypothesized that there is no any significant difference between pre-test scores of experimental group and control group; there is no any significant difference between 
pre-test scores and post-test scores of control group; there is a significant difference between pre-test scores and post-test scores of experimental group; there is a significant difference between post-test scores of the experimental group and the control group. The main goal of the psycho-training program is to increase optimism levels of the $8^{\text {th }}$ grade secondary school students, and the sub-goals of the program are to define the concept of the optimism and to conceptualize optimism and pessimism; to differentiate optimism and Pollyannaism; to be able to evaluate their own optimism level; to be able to give examples of optimism and pessimism thoughts from their own lives; to train the students verbalize their thoughts and feelings about their personal optimism behavior; to train the students differentiate feelings and thoughts and identify the relationship between thoughts and feelings; to train the students to be aware of negative thoughts and to be able to produce positive thoughts instead of negative thoughts; to be able to notice their irrational believes and be able to interrogate the irrational believes and convert irrational believes to the rational believes; to be able to differentiate the effect of optimism and pessimism on their bodily responses; to train the students to understand personalization And Generalization And The Possible Mistakes Done On Them.,

\section{Method}

Pre-test post-test control group design was used in the study. "Life Orientation Scale", which was developed by Scheier and Carver (1987) and adapted by Aydin and Tezer (1991), was applied to the 8th graders of Istanbul Avcilar Cigangir State School in 2014-2015 academic year. From 82 students 24 voluntary students with low optimism levels were selected, then, 12 of them were randomly assigned as experimental group, and the other 12 were assigned as control group. . The training program was only given to the experimental group for an hour and half per week for eight weeks to help the students (the experimental group) to enhance their optimism level. The control group wasn't exposed to any treatment. At the end of training, "Life Orientation Scale" (post-test) was again applied to the both experimental and control groups. All students were volunteers to join the study.

\section{Results}

For the analysis of the data Non-Parametric Mann- Whitney U test was used for inter-group differences and Wilcoxon Signed Rang Test was used for intra-group differences. The results showed that there is no significant difference between experimental group pre-test and control group pre-test. It means that the optimism levels in both experimental and control groups were similar before conducting the psycho-training program designed to increase optimism level. Also there is no significant difference between control group pre-test and control group post-test. The control group didn't expose to any treatment, so the optimism level of the students in control group haven't changed. There is no significant difference between experimental group post-test and control group post-test. However, there is a significant difference between experimental group pre-test and experimental group post-test. The main hypothesis in this study suggested that the psycho-training program would be effective on increasing the optimism level of secondary school $8^{\text {th }}$ grade students. The results showed that the applied program caused the increase of the optimism level in experimental group. The control group didn't show any significant differences in the optimism level scores.

\section{Discussion and Conclusion}

This study is based on cognitive-behavioral approaches. Most of the $8^{\text {th }}$ grade secondary school students are at the Formal Operations Stage according to Piaget cognitive development. The applied program was based on abstract thinking, so the students were able to change their negative thoughts and beliefs to positive thoughts and beliefs. The results of the study indicate that the psycho-training program designed to increase optimism levels has been effective in increasing optimism levels of the participants. Consequently, it can be said that such training was effective on increasing optimism level of $8^{\text {th }}$ grade secondary school students. Therefore, the effect of this program can be investigated on different variables (age, sex, etc.). Also the applied program may be conducted to other graders at public or private schools and compare the obtained results with the results of this study. Also follow-up study may be done using this psycho-training program and search for its permanency. 